\title{
COVID-19, Cyclone Amphan and Flood 2020: How the Government of Bangladesh Managed Multiple Disasters
}

\author{
Musabber Ali Chisty*, Nawshin Aforse, Mourupa Mohima \\ Institute of Disaster Management and Vulnerability Studies, University of Dhaka, Dhaka-1000, Bangladesh \\ Corresponding Author*
}

\begin{abstract}
Considering the population density of Bangladesh, existing poverty, vulnerable healthcare system and social structure, the recent COVID-19 outbreak control became a huge challenge for the government of the country. Apart from this rapidly transmitted virus, the addition of cyclone Amphan and monsoon flood almost all over the country accelerated the challenge to another level. Immediate after the declaration of the rapid surge of coronavirus pandemic, the Government of Bangladesh has initiated some strict measures to fight against the situation. The aim of this study is to critically analyze the necessary measures taken by the government to deal with this global pandemic, compounded by the super cyclone Amphan and early monsoon flood. The study is based on the secondary data sources which referred in depth views. Along with the 4,634 confirmed losses of lives till now, COVID-19 pandemic has created major impact in the economy that arises many problems. Also, the government had to undertake evacuate operation during the cyclone which eventually resulted 2.6 million affected people. From addressing the widespread of the pandemic to taking necessary steps such as creating awareness, suspension of international flights, imposing restrictions in movement, declaring lockdowns, announcing funds worth $\$ 8.56$ billion, assigning designated hospitals by the Ministry of Health and Family Welfare, the government has been trying to minimize the risk. Almost 70,000 CPP volunteers worked, nearly 2 million people were evacuated at risk during the cyclone. More than 1546 flood shelters, 387 medical teams and allocation of nearly BDT 9,200,000 cash including relief items were confirmed by the government to deal with the early wave of monsoon flood. In this short commentary, there is review of initiatives taken by the Bangladesh Government towards the current challenges. The study concluded with some recommendations to suggest the possible strategies to resist the growing trend of economy crushing pandemic of COVID-19, and contain with difficulties occurred due to cyclone Amphan and monsoon flood.
\end{abstract}

Key Words: COVID-19, Amphan, Flood, Multiple Disasters, Government, Management

\section{INTRODUCTION}

$\mathrm{T}$ The year 2020 has been a challenging year for the world as the apex predator race of the universe; the human is battling the SARS-COV-2 virus, becoming prey to microscopic organisms, and losing lives all over the world. With crown-like spikes on the outer body and a diameter of 65-125 nm, the virus comes from the Coronaviridae family and Nidovirales order containing a single-stranded RNA for nucleic material [1]. Even though the virus caught a large population in 2020, the inception of the outbreak is not unbeknownst to the world. Back in 2003, in Guangdong province, China, people were infected with a virus, identified to be a member of the Betacoronavirus subgroup, and was named SARS-CoV. It caused Severe Acute Respiratory Syndrome (SARS), in some cases leading to acute respiratory distress syndrome (ARDS) and took 776 lives, with 8000 affected all over the world [1]. Again in 2012, another Coronavirus emerged in Saudi Arabia, taking 838 lives and infecting 2428 people, after being confirmed as a member of Beta-coronavirus it was named the Middle East Respiratory Syndrome Coronavirus (MERS-CoV) [2]. Having camels as a zoonotic source or primary host the virus is also detected in Pipistrellus and Perimyotis bats [1].

In December 2019, a cluster of pneumonia cases, caused by a newly identified $\beta$-coronavirus, occurred in Wuhan, China [3]. Bats are assumed to be the reservoir for the SARS-CoV-2 as the genome sequence suggests. However, many intermediate carriers for the virus are still not completely withdrawn from suspicion. The outbreak had a breakthrough because of the Chinese New Year that is celebrated across China. As the aftereffect, a major increase in the numbers of the affected patients was noticed between January 10-22, 2020 [4]. Even though the speculation of mortality for SARS-COV-2 is $2 \%$, COVID-19 might result in death as a result of the preceding extensive alveolar damage, and failure of the lungs [4].

According to Coronavirus Situation Report - 184, the number of total COVID-19 confirmed cases around the world are $14,765,256$ and the total number of death is 612,054 [5]. In Bangladesh till now there are 210,510 confirmed cases of COVID-19 and 2,709 people are dead due to the virus [5]. Along with the loss of lives, COVID-19 has also created a major impact on the economy and livelihood around the world. From labor market supply disruption to fluctuation in consumption demand, COVID-19 has created major impacts and the consequences will continue [6].

On 16 May 2020, cyclone Amphan formed over the Indian Ocean and started moving towards the north-eastern parts of India and southern parts of Bangladesh [7]. According to research, cyclone Amphan was referred to as the super 
cyclone of the century [8]. On $20^{\text {th }}$ May 2020 the super cyclone Amphan turned into an extremely severe cyclonic storm and crashed on coastal areas of West Bengal, India. Onthe evening of $20^{\text {th }}$ May 2020, the cyclone Amphan entered Bangladesh with a wind speed of $150 \mathrm{~km} / \mathrm{h}$ creating an impact on 26 districts especially on Satkhira, Bagerhat, Khulna ,Chuadanga, Jessore, Patuakhali, etc. [7]. A major evacuation operation was undertaken before the landfall of the cyclone Amphan to save lives [9]. Along with the COVID-19 pandemic situation, it was difficult for the Government of Bangladesh to manage such an evacuation operation. According to a report by IFRC, a total of 26 people was killed, approximately 55,667 houses were destroyed and a large number of agro-products were destroyed worth of approximately BDT 3.25 billion. According to the Joint Needs Assessment total of 2.6 million people were affected due to the cyclone [10]. Among the affected population 0.82 million were women, 0.51 million were adolescent girls and boys, 0.14 million were elderly people, 27623 were people with disability, and 49316 pregnant women [10]. According to Joint Need Assessment (JNA) among the cyclone-affected union, the food stock of 74 percent of households was destroyed. In Satkhira, Bagerhat, and Khulna the impact on livelihoods was 83 percent, 43 percent, and 67 percent respectively on a scale of moderate to severe.

With the Coronavirus pandemic and the cyclone Amphan hitting Bangladesh in a row, the southern regions were still to recover from the cyclone, however, the monsoon flood came a bit early right after the cyclone. Heavy rain was reported in parts of Bangladesh due to the cyclone, district Ishwardi-in the west of the country recorded over $155 \mathrm{~mm}$ of rain in 24 hours to 21 May, a storm surge of 1.5 meters was reported along with parts of the country's low-lying coast and embankment collapsing was reported in Bagerhat District in Khulna Division, flooding nearby villages [11]. Later as the monsoon approached, the monsoon flood hit the Northern, North-Eastern, and South-Eastern region of Bangladesh- in 30 districts, as the peak flood-hit was anticipated on $18^{\text {th }}$ July 2020 [12]. The normal recovery period from a disaster is 3 to 5 years, however, the back-to-back flood of the last 3 years has made many dykes and embankments weak, 220 unions have already reported having their embankments damaged [12]. Over 90 people have died in flooding since 30 June, including 41 children, approximately 56,000 people have been displaced to 1,086 flood shelters, over 1,900 schools have been damaged, leaving 807,467 children without access to education [13].

The first wave of flooding began in late June and continued into July, as of 15 July, rivers were at severe flood levels (more than 1 meter above the danger mark) in 4 locations: the Brahmaputra river at Chilmari, Kurigram district (24.71 meters, the danger is $23.70 \mathrm{~m}$ ); the Jamuna river at Bahadurabad (20.74 $\mathrm{m}$, danger is $19.5 \mathrm{~m}$ ); the Jamuna at Sariakandi (17.82 $\mathrm{m}$, danger is $16.7 \mathrm{~m}$ ); and the Jamuna at Kazipur (16.19 meters, the danger is $15.25 \mathrm{~m}$ ) [14]. As of July
31, the Bangladesh Flood Forecasting and Warning Centre reported water levels along the Jamuna River were at or above "danger level." [15]. However, the leading daily Dhaka Tribune reports as of 26th august, Of the total 101 river points monitored in the country, water levels went up at 24 stations, while decreased at 72 stations and remained stable at five points [16].

\section{OBJECTIVE OF THE STUDY}

The main objective of the study is to critically analyze the steps taken by the Government of Bangladesh (GoB) to manage the COVID-19, cyclone Amphan and the monsoon flood at the same time as a multiple disaster condition. Also, the study is focused to point out gaps and shortcomings of different disaster management strategies.

\section{METHODOLOGY OF THE STUDY}

The study is fully based on secondary data sources. Due to the COVID-19 situation, it is not secured to conduct any field visit to collect primary level data. In this regard different journal articles, newspaper articles, webpages, and reports developed by government and non-government organizations, etc. are reviewed to get an in=depth view about initiatives taken by the GoB to manage multiple disasters. In searching the secondary resources the study mainly focused on words like COVID-19 in Bangladesh, Amphan in Bangladesh, Monsoon Flood in Bangladesh, COVID-19 Response Mechanism of Government of Bangladesh, Managing Cyclone Amphan by the Government of Bangladesh, Managing 2020 Flood in Bangladesh by the Government, etc. For scholarly articles, the study mainly focused on two different sources which are Google Scholar and Microsoft Academic. For newspaper based information the study mainly focused on news from reputed national dailies. Also, information from reliable web pages and reports were referenced for the study. A special screening and selection process was followed to use the information only from relevant and credible sources. The study fully followed the ethical bindings which should be considered while conducting research. All the sources of the information for the study is scientifically referenced and acknowledged.

\section{FINDINGS}

In the findings, the study discussed initiatives taken by the Government of Bangladesh in terms of managing the impact of COVID-19, cyclone Amphan and flood. The initiatives are discussed according to the headings of the disasters.

\section{A. Managing COVID-19 by the Government of Bangladesh (GoB) \\ 1. Planning by the GoB before the surge of COVID-19 in Bangladesh}

The government of Bangladesh (GoB) has initiated the National Preparedness and Response Plan for COVID-19, Bangladesh before the surge of COVID-19 in Bangladesh. To smoothen planning and detect response levels, 6 country 
levels have been detected according to COVID19 infection standing[17]. The risk evaluation should take into deliberation common key factors such as clinical gravity of the illness such as its clinical course, comorbid illness and any serious outcomes leading to loss of life; transmissibility of the infection, and the capacity of assisting community-level outbreaks; geographical open out of the COVID-19 in living beings; accessibility of preventive acts; vulnerability of the mass people; effect on healthcare substructure, risk of transference in healthcare settings; and guidance by international health authorities[17].

\section{Pointing focal IEDCR as the focal organization to share COVID-19 related information}

The virus was established to have spread to Bangladesh in March 2020[18]. The first three known cases were testified on 8 March 2020 by the country's epidemiology institute, IEDCR[19]. Consistent press briefings and data released by the Institute of Epidemiology, Disease Control and Research (IEDCR), the official source of COVID-19 information in Bangladesh. These include daily data on the number of tests, positive cases, deaths, recoveries, and case whereabouts as well as statistics on medical records, particularly supplied for coronavirus preparation. The spatial mapping on district-wise COVID-19 widespread was framed under the concerns of GoB[20].

\section{Special rules and directions by the Ministry of Health and Family Welfare (MOHFW)}

Bangladesh started the mitigation process at a very early stage and publishing a guideline is a part of the case supervision of COVID-19 in Bangladesh with specific thought under MOHFW and other Governmental organizations[21]. Such as all-inclusive infection prevention and control (IPC), case explanation of suspect, likely and confirmed COVID-19 will be trailed by every medical specialist of Bangladesh which will be updated frequently, the notion of testing, tracking, tracing, isolation, and quarantine of close interactions will be tracked, the severe and serious cases will be treated in COVID-19 selected hospitals, there are no specific treatments found to be useful for COVID-19 yet; consequently, the backbone of management is initial diagnosis and prime supportive care to released symptoms and to assist organ function in more severe sickness,etc. [21].

\section{Suspension of international flights}

Bangladesh has put a hold on flights to all countries except the UK and China until April 15 because of the global outbreak of COVID-19[22]. Earlier on March 21, international business passenger flights with 10 counties Malaysia, Oman, Singapore, Qatar, Kuwait, Saudi Arabia, United Arab Emirates, Turkey, India, and Bahrain were put a hold on. On March 15, GoB suspended on-arrival visas for all nations for two weeks. Besides, travelers will not be allowed to get in Bangladesh from all European nations except the UK until
March 31. On March 19, Biman Bangladesh Airlines suspended all of its flights to Dubai and Abu Dhabi [22].

\section{Closure of educational institutions}

The government has been beholding a nationwide general holiday since March 26, which was carried on till May 5, to hold the outbreak of the coronavirus pandemic and keep up social distancing[23]. The educational institutions have persisted closed since March 17 in the country. For the time being, Prime Minister Sheikh Hasina on April 27 indicated that schools, colleges, and other educational institutions might continue to be closed till September if the Covid-19 situation remains the same[23].The straight and almost all instant impact of the Covid-19 on the education sector is learning opportunities deprivation. More than 36.0 million pupils (inclusive of 17.0 million in the primary) are currently out of school[24].

\section{Assigning designated hospitals for COVID-19 patient care}

According to National Preparedness and Response Plan for COVID-19, Bangladesh three hospitals of Dhaka city (Kurmitola, Kuwait Moitree, and Infectious Diseases Hospital) have been chosen for being in charge of the patients in isolation, but around 500 hospitals are chosen for initial care of the COVId-19 patients with light illness and symptoms [17]. Based on the exacerbation of the state of affairs, high dependence aid along with ICU provision will be strengthened. Significance will be given for safeguard medical clinic acquired inflammation and safety of the frontline peoples both at the health care equipment and house as well as the community[17].

\section{Announcing general holiday}

The country announced its first cases on March 8 and the first casualty on March 18. Regardless of a large scale of measures taken by the government, the digits of confirmed cases and casualties continue to rise. On March 23, the government announced general holidays from March 26 to April 4 and after that extended it numerous times to May 30[25]. State Minister Hossain told all public, private, and autonomous offices, organizations can be unlocked on a restricted scale from May 31 to June 15 but every person has to work according to the 13 health directives issued before[25].

\section{Imposing restrictions on movement}

Central Technical Committee for Zoning to Mitigate COVID19 had distributed an ideal operation guideline advocating that a zone be placed under lockdown for 21 days, which would be announced by the district civil surgeons[26]. The guidelines allowed people to work from home (WFH) in the lockdown zones in the areas but allowed agricultural and industrial works to maintain the health and safety guidelines outside the urban areas. It put a pause on any type of transport-related movement if a zone was under lockdown but allowed movements of trucks, cargo careers, and vessels after daylight in the red zone areas outside the urban areas. The grocery 
shops, medicine shops inside the restricted zones would remain open and the food shops would be allowed to deliver foods in the red zones.

\section{Deploying special forces}

As per the GoB directive, the army will make obligatory coordination as part of the deployment to help the local administration in controlling the Covid-19 in all districts under the "In Aid to Civil Power" act[27]. The GoB decided to deploy the armed forces to control the transmission of the coronavirus which has been declared as a pandemic. The army will also assist with medical assistance at the division and district levels. The Bangladesh Navy will initiate to assist the civil administration in coastal areas. The Air Force will be in charge of the hospital's medical kit and emergency transportation.

\section{Increasing testing centers}

The GoB has decided to increase the number of medical institutions conducting Covid-19 tests for the benefit of foreign passengers and to make sure health standards. The decision was declared at a meeting between the Ministry of Health and the Ministry of Civil Aviation and Tourism. The number of hospitals with testing facilities in Dhaka has been expanded. The capital's Combined Military Hospital (CMH) is on the list of hospitals to be provided with testing facilities[28]. GoB had strong preparedness for the treatment of the citizens from the very early stage of coronavirus. New initiatives are being declared every day including increasing the number of tests [29].

\section{Signing memorandum with private hospitals to provide health care to COVID-19 patient}

The GoB has decided to bear the operational charges of undersigned non-governmental hospitals treating Covid-19 patients. Medical professionals and others working at these clinics will be salaried by the government. The Health Service Division under the Health and Family Welfare Ministry recently signed aMoU with Dhaka's Holy Family Red Crescent Medical College and Hospitals in this context. Anwar Khan Medical College Hospital, Dhanmondi, and Impulse hospital are also planning to treat coronavirus patients[30]. United Hospital signs MOU with DGHS (DirectorGeneral ofHealthServices) for the joint alliance to conduct Munshiganj isolation midpoint for COVID19 suspect or positive patients [31].

\section{Suspension of public transportation}

Experts declared a restriction on passenger travel via water, rail, and on domestic air routes from March 24 while all public transport on streets will be banned from March 26 to stop the transmission of the virus, formally known as COVID19. The Bangladesh Railway Authority has also banned all local, commuter, and mail train facilities across the nation[32].After that strict bans would remain on local transports and inter-district travels crossways Bangladesh until May 30 during the extended lockdown, according to the GoB[33]. Road transport, water transport, rail transport, and domestic flights will remain shut. Only transports of emergency services will be allowed to move according to the government. The travel restrictions would also begin four days before Eid and continue for two days after the celebration. No transports, including private cars, will be allowed on the streets during the phase[33].

\section{Lockdown of areas, Upazilas, districts, etc.}

The nationwide lockdown orders have been followed since March 26 with the GoB extending the lockdown period in phases, further until May 30 among a flow in coronavirus cases and casualties across the nation[34]. Mayors in the city corporation areas and deputy commissioners in the remaining sectors of the country would implement fresh restrictions in the red zones according to the director-general of health services' guidelines. Dhaka North City Corporation mayor followed by the DGHS, following the National Technical Advisory Committee for fighting COVID-19, announced names of 45 areas in the capital, 11 in Chattogram, 4 in Narayanganj, and 5 in Gazipur as red zones without mentioning the areas to be placed under lockdown [34].

\section{Issuing special health guidelines from time to time}

The Directorate General and Health Service have deliveredallinclusive technical guidelines including all sectors to remove restrictions on businesses, other necessary services, and maintain health guidelines to contain the COVID-19 pandemic[35]. Agreeing to the guidelines, all communication facilities need to maintain protective equipment such as masks and disinfectants and monitor all travelers for high temperatures at entry spots. According to the guidelines, the people should sanitize all spaces of their houses and they must follow hygienic lifestyles containing washing their hands with soap, wearing masks, gloves let alone other detrimental behaviors[35]. In comeback to the crisis, Bangladesh (BWB) guideline on COVID 19 will help employers, operatives, and respective committee associates responsible for handling their workstation during the pandemic, protecting workers and replying some of the workplace safety and health (OSH) related queries that factories are facing [36].

\section{Distributing safety items like mask, gloves, hand sanitizers}

The government acknowledged face masks and hand sanitizers as must-have commodities during the pandemic days as it stepped up efforts to boost supply and prevent hoarding of these items in its fight to check the spread of coronavirus disease[37]. PRAN-RFL Group helping the GOB has distributed protective equipment among civil servicers and health workers in Chattogram for their safety during a pandemic. The group also provided corona sample collection booths, surgical masks, PPE, hand gloves, and hand sanitizers to the Director-General of Health Services (DGHS) and 10 hospitals in Dhaka and Bhola[38]. State Minister for Foreign Affairs MdShahriarAlam has provided safety equipment to the 
physicians, nurses, and healthcare employees working for Covid-19 patients' treatment in Rajshahi with his own expense[39].

\section{Introducing special funds for paying the salary of $R M G$ sector workers}

The GoB declared a set of incentive packages worth $\$ 8.56$ billion on 5 April 2020 to fight the impact of coronavirus in Bangladesh[40]. Affected clothing factories availed funds from the $\$ 600$ million contracts in loans at $2 \%$ interest to pay their workers' wages for up to 3 months - paid into either a bank or mobile monetary services account[40]. Employers and workers in readymade garments and footwear factories should utilize this planning guidance to assist identify risk levels in workstations settings and to determine any suitable control measures to apply[36].

\section{Initiating online classes for schools}

The GoB with reinforcing from the World Bank took action on the process of digitalizing higher education of Bangladesh throughout the Higher Education Quality Enhancement Project (HEQEP) in 2009. BdREN, an initiative of HEQEP, started laying the footings of digitized substructure for higher education institutions by setting up high bandwidth and firm network integration at organizations. Despite these efforts, no online classes were offered by native universities. In March, when UGC issued its instruction, BdREN acknowledged it by assisting universities formatting institutional accounts on Zoom, an online platform already educators friendly which was well-received during the pandemic. They also assisted teachers and university faculty get familiar with creating accounts, classroom management and assessment, and tips on making virtual classrooms better organized. BdREN also builds a hotline to help students with network connection problems[41].

\section{B. Managing Amphan in Bangladesh by the Government of Bangladesh (GoB)}

\section{Issuing warnings according to the position of the cyclone}

From the very beginning of the formation of the cyclone Amphan, the Government of Bangladesh (GoB) was very alert. On May 16, 2020, Bangladesh Meteorological Department (BMD) issued Distant Warning Signal No. 2 as the deep depression in the Bay of Bengal area converted into a cyclonic storm named "Amphan" [42]. On May 18, 2020, BMD issued Danger Signal No. 7 for the coastal districts including Satkhira, Bagerhat, Khulna, Jhalokathi, Borguna, Pirojpur, Patuakhali, Bhola, Barishal, Noakhali, Chandpur, etc. [43]. BMD issued Great Danger Signal No. 10 for most of the coastal districts on May 20, 2020. On the same day, the cyclone slammed into the areas of West Bengal in the morning and it entered Bangladesh in the evening with a wind speed of $150 \mathrm{kmph}$ [7].

\section{Spreading early warnings in the risky zones}

When cyclone Amphan was forming in the Bay of Bengal different agencies from the Government of Bangladesh (GoB) initiated emergency preparedness and response planning activities. One of the major entities regarding cyclone response is the Cyclone Preparedness Programme (CPP) of GoB. There are a total of 70,000 CPP volunteers who start working from the early stage of cyclone formation. CPP volunteers mainly get the responsibility of spreading warnings and raising warning flags in the coastal zone. Like other previous cyclones during Amphan all the CPP volunteers disbursed warning among people of the coastal areas. Due COVID-19 situation the volunteers followed all the guidelines developed by the GoB[44].

\section{Evacuating people at risk and providing shelters to evacuated population}

More than 2 million people were evacuated from the coastal districts of Bangladesh. Mainly CPP volunteers were responsible to evacuate all the people. Due to the COVID-19 situation to maintain health safety GoB prepared more than 12,000 shelters which were three times higher than the usual number [44]. The government ensured that there was plenty of space to maintain physical distancing in the shelters.

\section{Sharing information about maintaining health guidelines in shelter centers}

Bangladesh Red Crescent Society (BDRCS) and CPP volunteers were implementing the directions from the GoB to share information related to health safety in the cyclone shelter centers [44]. Also, the government regularly ensured to share COVID-19 related information through mass media like television, radio, and newspapers. Also, social media were used to share health-related information during the cyclone.

\section{Distributing health safety items with evacuated population}

Volunteer groups and GoB ensured distribution of health safety items in the shelter centers during Amphan, These health safety items included hygiene parcels, first aid kits, masks, sanitizing items, etc. [44].

\section{Providing basic relief items to impacted population}

GoB of Bangladesh (GoB) immediately initiated a relief program for the cyclone-affected population. A total of 3,100 metric tonsof rice was allocated for the people of affected districts. A total of 5 million BDT for cash support, a total of 3.1 million BDT for buying child food, and a total of 2.8 million BDT for buying animal food were allocated for cyclone-affected areas [45]. Bangladesh Armed Forces also helped in distributing the relief items [46].

\section{Supporting with recovery initiatives}

As a recovery and reconstruction initiative after the cyclone AmphanGoB allocated cash support to buy logistics to repair damaged houses through the Department of Disaster Management (DDM) under the Ministry of Disaster 
Management and Relief (MoDMR). More than 136 million BDT was allocated to buy and distribute the Corrugated Iron Sheet (CIS) [47].

\section{Repairing dams and embankments}

After the cyclone, it was estimated that more than $150 \mathrm{~km}$ of embankments were damaged due to the cyclone Amphan[48]. Under the direction and support of the Ministry of Water Resources (MOWR), Bangladesh Army started working to repair the damaged embankments. Bangladesh Army continued to support the ministry to repair the embankments in the shortest time [49]. Also, GoB has a mega project to make the embankments more sustainable with a project of 10 million BDT [49].

\section{Managing Monsoon Flood by the Government of Bangladesh (GOB)}

\section{Issuing early warnings}

Since March 2020, northern, southern and eastern districts have been facing Cautionary Signal No. I and Warning Signal No. II signals for Inland River Ports with heavy rain warnings. However, the heavy rain warning became a regular since late May till mid-July. On 27 June, the increasing water level in the Teesta river point in Lalmonirhaat was notified but no evacuation warning was officially declared. According to the Flood Forecasting and Warning Centre (FFWC) bulletin on 12 July 2020, water levels of all major rivers in the upper Meghna basin, Brahmaputra-Jamuna, and Ganges basins are in rising trend till 12 July morning and it may continue in the next 72 hours due to onrush of upstream water coupled with heavy to very heavy rainfall [50]. Flood Forecasting and Warning Center, Ministry of Water Resources, Bangladesh, Bangladesh Water Development Board (BWDB), Bangladesh Water Resources Planning Organization (WARPO), Joint River Commission (JRC), Bangladesh, Bangladesh Haor\& Wetland Development Boardhave been since collaborating and sharing early warnings, that is cumulatively published as daily reports in Department of Disaster Management (DDM), Bangladesh's website. Due to the acute shortage of food, pure drinking water, and poor sanitation system, there is a possibility of a communicable disease outbreak when flood water will start receding [12].

\section{Evacuating at-risk population}

By 30 July 2020, 33 districts with had 5,116,424 affected people, 1546 flood shelters sheltering 64,739 people and 78081 livestock animals, and 387 continuing medical teams provided by the government [51]. On 15 August 1103 shelter centers were open in 33 districts. The government, by $31^{\text {st }}$ August, sheltered 62,823 people in government and nongovernment shelters, 46076 people in temporary shelters. By $4^{\text {th }}$ September the water level in rivers is reported normal and since early September no more evacuation was reported.

\section{Distributing relief items}

The Government of Bangladesh has allocated total 8,210 metric tons of rice, BDT 22,250,000 (approximately CHF 242,235 ) of cash, 48,000 packets of dry foods, BDT 4,800,000 (approximately CHF 52,258) worth of fodders (animal foods), and BDT 4,800,000 (approximately CHF 52,258) worth of child foods to 23 districts from 28 June to 9 July. Each district will receive 200 metric tons of rice, BDT 500,000 cash (approximately CHF 5,443), BDT 200,000 (approximately CHF 2,177) worth of child food, BDT 200,000 (approximately CHF 2,177) worth of fodder, and 2,000 packets of dry foods [52]. Also, 400 bundles of corrugated iron sheets were distributed among the victims, Lalmonirhaat receiving the most numbered 200.

\section{Providing cash supports}

On the report of 15 August it was stated that of BDT $4,27,00,000$ allocation of cash for relief BDT 2,88,81,700 was distributed and BDT $1,38,18,300$ is still remaining. Aside from that for housebuilding allocation of BDT 1200000 only BDT 300,000 was given out and BDT 900,000 remains. In total government had the allocation for BDT 92,000,000 from 26 June to 10 August for livestock feed, cash relief, child food support, and house reconstruction in all of 33 districts. However, only Rajbari, Shariatpur, and Lalmonirhaat received cash for the reconstruction of houses since the effects were devastating in those districts[53].

\section{Sharing COVID-19 related information with flood-affected population}

To co-ordinate a response to flood-affected districts with due consideration for the COVID-19 situation, WHO and DGHS organized a special meeting with divisional directors of Dhaka, Mymensingh, Rangpur, Rajshahi, and Sylhet, all civil surgeons, and Upazilla Health and Family Planning Officer (UHFPO) of the affected areas [54]. The government had issued suggestions to districts to maintain social distancing when distributing relief and reported every district's social safety measure while tending the victims with reliefs and aids. DGHS and WHO monitored the overall flood situation as the leads from National Health Emergency Control rooms of DGHS and no severe disease outbreak and shortage of emergency drugs in flood-affected districts were reported [54].

\section{Distributing health safety items to the affected population}

Working alongside the government, UNFPA began giving communities at risk in the Bogura, Gaibandha, Kurigram, Jamalpur, and Sirajgonj districts the means to protect themselves and their livelihoods from the worst effects of the floods. UNFPA is delivering hygiene kits, dignity kits, and health kits to 15,000 women and girls and the transgender community, providing them essential sexual and reproductive health supplies. The kits will also include flashcards with COVID19 precautionary measures, as well as helplines to report incidents of gender-based violence and to receive 
psychosocial support [55]. Approximately, 866 Medical team worked for assisting the affected[56]. Total 1,013 Hygiene Kit, 2,254 Kg Bleaching powder were distributed [57]

\section{Collaboration and information sharing}

This year the government again collaborated with 65 other non-government organizations to produce "Monsoon Floods 2020 Coordinated Preliminary Impact and Needs Assessment", with CARE, UNOPS, and UKAid. This is a joint needs assessment for the working groups on floods in Bangladesh. The Needs Assessment Working Group (NAWG) is the platform for government and nongovernment humanitarian agencies under the Humanitarian Coordination Task Team (HCTT). The secretariat of the Working Group is hosted by CARE Bangladesh under the "Supporting Bangladesh Rapid Needs Assessment (SUBARNA) Project" [12].

\section{CONCLUSION AND RECOMMENDATIONS}

An economy crushing pandemic, a super cyclone, and a hardhitting flood all in one same year is a nightmare for any acting government of a developing nation, even for Bangladesh. However, the government of Bangladesh has withheld strongly against the series of disasters in 2020. Bangladesh has reported 5.24 percent GDP growth in FY 2019-20 with the coronavirus pandemic ravaging the economy for at least a third of the financial year [58]. The choice of disclosing a monetary upgrade bundle of about 8 billion USD to counter the unfriendly impacts of the pandemic by the government can be implemented if they temporally postpone all non-essential developmental works to gather a modest amount to support people in fighting this crisis [18].

Using this period of change the government did adopt new methods to cope with unexpected situations like floods, cyclones. But the challenge in those crises is yet to be grasped firmly. Based on the reports of observed situation of cycloneaffected areas and the flood-affected areas in Bangladesh amidst the SARS-COV-2 virus pandemic the following recommendations are proposed-

- The government should include multiple disaster management strategies in the current disaster management policies and plans.

- Counseling the members related to relief at the local level about proper behavior in relief distribution.

- Using administration at the district level to monitor and assist the relief process.

- Disaster management expertise deployment suiting the crisis and the region.

- The government has been doing its best with the resources; however, the human resource at hand needs a major upgrade in skills.

- A large scale nationwide geographic evaluation of land and water both.

\section{ACKNOWLEDGEMENT}

This study acknowledges the authors and literatures which were used to develop the results and findings. The study also acknowledges the proof readers and personal reviewers for their support.

- Regular and thorough Environment Impact Assessment for any projects regarding river and riverbank construction

- Uniform design for shelter centers in every district

- A long term environmentally appropriate approach in rural infrastructures.

- Strengthen disaster preparedness and early warning in flood, easy language, and dependable medium

- Strengthening public morale by properly introducing various policies related to any disaster and a decentralized approach in the promotion of various early warning for various disasters.

- Accepting new technologies in various phases of managing disasters.

- The allocation of a stimulus package of 2.5 billion USD for creating a bridge financing the amount should be incorrect channels [59]

- Ensuring the responsibility and accountability of cabinet members and poor services of the hotlines for protective equipment and testing kits etc.

- The government should come up with strong protocols to make people follow the safety instructions and also, more and more public awareness campaigns should be organized.

Additional measures must be taken promptly, anticipating the potential challenge that would be faced by the hospitals in the case of an upsurge of COVID-19 cases. The fight against COVID-19, Cyclone Amphan, and Flood cannot be carried out by the government alone. It will require an unprecedented level of coordination between the public and private at the local and international levels.

\section{REFERENCES}

[1] M. Adnan, S. Khan, A. Kazmi, N. Bashir, and R. Siddique, "COVID-19 infection: Origin , transmission, and characteristics of human coronaviruses," J. Adv. Res., vol. 24, pp. 91-98, 2020, doi: $10.1016 /$ j.jare.2020.03.005.

[2] L. C. O'Keefe, "Middle east respiratory syndrome coronavirus," Workplace Health and Safety, vol. 64, no. 5. pp. 184-186, 2016, doi: $10.1177 / 2165079915607497$.

[3] Y. Guo et al., "The origin, transmission and clinical therapies on coronavirus disease 2019 ( COVID-19) outbreak - an update on the status," Mil. Med. Res., vol. 7, no. 11, pp. 1-10, 2020.

[4] R. Sheervalilou et al., "COVID - 19 under spotlight: A close look at the origin , transmission, diagnosis , and treatment of the 2019 nCoV disease," J. Cell. Physiol., no. April, pp. 1-52, 2020, doi: 10.1002/jcp. 29735.

[5] World Health Organization, "Coronavirus Situation Report - 184," 2020. doi: 10.1213/xaa.0000000000001218.

[6] W. J. McKibbin and R. Fernando, "The Global Macroeconomic Impacts of COVID-19: Seven Scenarios,” 2206-0332, 2020.

[7] International Federation of Red Cross and Red Crescent Societies, "Operation Update Report Bangladesh : Cyclone Amphan," 2020. 
[8] G. Das, "Amphan - Maiden Super Cyclone of the Century,” May 2020.

[9] Aljazeera, "Cyclone Amphan kills dozens, destroys homes in India, Bangladesh," 2020. https://www.aljazeera.com/news/2020/05/cyclone-amphan-leavestrail-destruction-bangladesh-india-200521035745307.html (accessed Jul. 29, 2020).

[10] NAWG CARE Bangladesh, "Cyclone Amphan Joint Needs Assessment (JNA)," no. May, 2020, [Online]. Available: https://www.humanitarianresponse.info/sites/www.humanitarianre sponse.info/files/documents/files/cyclone_amphan_joint_needs_as sessment_nawg_31052020.pdf.

[11] FLOODLIST NEWS, "India and Bangladesh - Torrential Rain from Cyclone Amphan Triggers Flooding - FloodList,” 2020. http://floodlist.com/asia/india-bangladesh-cyclone-amphan-floodsmay-2020 (accessed Aug. 26, 2020).

[12] Need Assessment Working Group, "Monsoon Floods 2020 Coordinated Preliminary Impact and Needs Assessment Bangladesh Needs Assessment Working Group," no. July, 2020, [Online]. Available: file:///C:/Users/user/Downloads/nawg_monsoon_flood_preliminar y_impact_and_kin_20200802_final.pdf.

[13] FLOODLIST NEWS, "Bangladesh - Monsoon Floods Affect 3.3 Million - FloodList," 2020. http://floodlist.com/asia/bangladeshmonsoon-floods-update-july-2020 (accessed Aug. 26, 2020).

[14] FLOODLIST NEWS, "Bangladesh - Floods in 15 Districts Affect Almost 1.4 Million - FloodList," 2020. http://floodlist.com/asia/bangladesh-floods-update-july-2020-2 (accessed Aug. 25, 2020).

[15] NASA, "Intense Flooding in Bangladesh," Jul. 2020.

[16] Dhaka Tribune, "Flood situation improves across the country | DhakaTribune,"2020.

https://www.dhakatribune.com/bangladesh/nation/2020/08/26/wat er-level-in-ganges-basin-continues-to-remain-steady (accessed Aug. 26, 2020).

[17] OCHA, "National Preparedness and Response Plan for COVID19, Bangladesh - Bangladesh | ReliefWeb," Jul. 2020. https://reliefweb.int/report/bangladesh/national-preparedness-andresponse-plan-covid-19-bangladesh.

[18] S. Anwar, M. Nasrullah, and M. J. Hosen, "COVID-19 and Bangladesh: Challenges and How to Address Them," Front. Public Heal., vol. 8, no. April, pp. 1-8, 2020, doi: 10.3389/fpubh.2020.00154.

[19] IDARE, "Bangladesh COVID-19 Scenario \& Trend," 2020. https://covid19bd.idare.io/.

[20] R. K. Biswas, S. Huq, A. Afiaz, and H. T. A. Khan, "A systematic assessment on $<$ scp $>$ COVID $</$ scp $>-19$ preparedness and transition strategy in Bangladesh," J. Eval. Clin. Pract., p. jep.13467-jep.13467, Aug. 2020, doi: 10.1111/jep.13467.

[21] Directorate General of Health Services and Ministry of Health and Family Welfare, "National Guidelines on Clinical Management of Coronavirus Disease 2019 ( Covid-19 )," vol. 2019, no. March, pp. 0-28, 2020, [Online]. Available: file:///C:/Users/Lenovo/Downloads/COVID_Guideline_V4.30.3.2 020 (1).pdf.

[22] UNB, "Bangladesh suspends flights to all countries except China, UK," 2020.

[23] D. Tribune, "Covid-19: Educational institutions engaging in online, virtual classes | Dhaka Tribune," May 2020. https://www.dhakatribune.com/bangladesh/education/2020/05/02/ covid-19-educational-institutions-engaging-in-online-virtualclasses.

[24] T. F. Express, "Effects of the pandemic on the education sector in Bangladesh," Jul. 2020. https://thefinancialexpress.com.bd/views/effects-of-the-pandemicon-the-education-sector-in-bangladesh-1592061447.

[25] UNB, "Coronavirus: Govt not extending general holidays," May 2020. https://unb.com.bd/category/bangladesh/coronavirus-govtnot-extending-general-holidays/52152.

[26] E. K. and R. Ahamad, "Red zone declaration process in a mess," Jun. 2020.
[27] T. B. Standard, "Armed forces deployed in all districts to control the coronavirus | The Business Standard," Mar. 2020.

[28] D. Tribune, "Government to increase Covid-19 test facilities at hospitals for overseas passengers | Dhaka Tribune," Jul. 2020.

[29] UNB, "Coronavirus sample testing to be increased to 15,000 a day soon: Health Minister," May .

[30] S. and R. Mamun Mizanur, "Govt to bear costs of private hospitals treating Covid-19 patients | Dhaka Tribune," May 2020.

[31] United Hospitals Ltd., "United Hospital signs MoU with DGHS (Directorate General of Health Services) for joint collaboration to operate Munshiganj Isolation Centre for Corona Virus (COVID19) suspect/positive patients - United Hospital," 2020. https://www.uhlbd.com/news/united-hospital-signs-mou-withdghs20.

[32] N. Kamruzzaman and Sakib, "Bangladesh imposes total lockdown over COVID-19," Mar. 2020. https://www.aa.com.tr/en/asiapacific/bangladesh-imposes-total-lockdown-over-covid$19 / 1778272$.

[33] T. Statesman, "Bangladesh extends restrictions on public transport, travels until May 30 - The Statesman," May 2020.

[34] E. and A. Kamol Rashad, "General holiday for red zones in Bangladesh announced,” Jun. 2020.

[35] T. B. Standard, "DGHS issues comprehensive technical guidelines to contain Covid-19 | The Business Standard," May 2020. https://tbsnews.net/coronavirus-chronicle/covid-19bangladesh/dghs-issues-comprehensive-technical-guidelinescontain.

[36] IFC, "COVID-19 Management Guidance for factories in Bangladesh - Better Work," 2020 https://betterwork.org/portfolio/covid-19-management-guidancefor-factories-in-bangladesh/.

[37] New Age, "1 jailed, 29 fined for hoarding, hiking mask price," 2020. https://www.newagebd.net/article/101876/1-jailed-29-finedfor-hoarding-hiking-mask-price (accessed Sep. 09, 2020).

[38] UNB, "PRAN-RFL donates protective equipment to police, health workers in Ctg," Jun. 2020. https://unb.com.bd/category/business/pran-rfl-donates-protectiveequipment-to-police-health-workers-in-ctg/53452.

[39] T. B. Standard, "State Minister Shahriar gives safety equipment to healthcare providers in Rajshahi | The Business Standard," Apr. 2020.

[40] BetterWork, "Bangladesh Updates - Better Work," 2020. https://betterwork.org/2020/04/15/bangladesh-updates/.

[41] M. Rahman, "COVID-19 boosts digitization of higher education in Bangladesh," Aug. 2020. https://blogs.worldbank.org/endpovertyinsouthasia/covid-19boosts-digitization-higher-education-bangladesh.

[42] Bdnews24.com, "Warning Signal No. 2 as depression turns into cyclone"Amphan,"'2020. https://bdnews24.com/bangladesh/2020/05/16/warning-signal-no.2-as-depression-turns-into-cyclone-amphan (accessed Sep. 07, 2020).

[43] Dhaka Tribune, "Super cyclone Amphan barrels toward Bangladesh," 2020. https://www.dhakatribune.com/bangladesh/2020/05/18/supercyclone-amphan-barrels-towards-bangladesh (accessed Sep. 07, 2020).

[44] International Federation of Red Cross and Red Crescent Societies, "Emergency Plan of Action ( EPoA ) Bangladesh: Cyclone Amphan A Situation Analysis," 2020.

[45] Department of Disaster Management, "Relief Item and Allocation Notice," 2020.

[46] The Business Standard, "Armed forces step in post-cyclone recovery," 2020. https://tbsnews.net/environment/cycloneamphan/armed-forces-step-post-cyclone-recovery-84286 (accessed Sep. 08, 2020).

[47] Department of Disaster Management, "Housing Item Allocation," 2020.

[48] The Daily Star, "Repair embankments damaged in Cyclone Amphan on urgent basis," 2020. https://www.thedailystar.net/country/news/repair-embankments- 
damaged-cyclone-amphan-urgent-basis-1905421 (accessed Sep. 08, 2020).

[49] Dhaka Tribune, "Govt taking Tk100cr project to repair embankments,"2020.

https://www.dhakatribune.com/bangladesh/2020/05/28/zahidfaruk-govt-taking-tk100cr-project-to-repair-embankments (accessed Sep. 08, 2020).

[50] International Committee of the Red Cross, "Information bulletin Bangladesh: Floods The situation," 2020. [Online]. Available: file:///C:/Users/user/Downloads/daily

flood reports/IBBDfl130720.pdf.

[51] Department of Disaster Management, "Daily Disaster Report 30.07.2020," 2020 .

[52] International Committee of the Red Cross, "Information bulletin Bangladesh: Monsoon Floods," 2020. [Online]. Available: file:///C:/Users/user/AppData/Local/Mendeley Ltd./Mendeley Desktop/Downloaded/Unknown - Unknown - Glide n ${ }^{\circ}$ FL-2020000161-BGD.pdf.

[53] Department of Disaster Management, "Daily Disaster Report 31.08.2020,"2020.[Online].Available:

file:///C:/Users/user/Downloads/daily flood reports/2020-09-0216-32-c6ecf59e20d4b47b670f8e3951b1e3bc destroction details.pdf.

[54] World Health Organization, "WHO Bangladesh COVID-19 Morbidity and Mortality Weekly Update," vol. 21, no. 182-183, pp. 60-66, 2020, [Online]. Available: file://C:/Users/user/Downloads/daily flood reports/who-covid-19update-21-20200720.pdf.

[55] UNHCR, "United Nations Nations Unies Office for the Coordination of Humanitarian Affairs," 2020. [Online]. Available: file:///C:/Users/user/AppData/Local/Mendeley Ltd./Mendeley Desktop/Downloaded/Unknown - Unknown - United Nations Nations Unies Office for the Coordination of Humanitarian Affairs.pdf.

[56] Need Assessment Working Group, "Needs Assessment Working Group Bangladesh BANGLADESH Response Modality and Type of Organization Access to the Fund by Type of Organization," 2020.[Online].Available:

https://public.tableau.com/views/Flood4W1stRound/Sheet24?:lang uage $=$ en \&:display_count=y\&:origin=viz_share_link.

[57] Need Assessment Working Group, "Needs Assessment Working Group (NAWG) Bangladesh Monsoon Floods 2020 Coordinated Preliminary Impact and Needs Assessment," 2020.

[58] The Financial Express, "BD economy grew 5.24pc in FY20 amid pandemic," The Financial Express, 2020. https://thefinancialexpress.com.bd/economy/bd-economy-grew524pc-in-fy20-amid-pandemic-1597136362.

[59] New Age, "GOVERNMENT MEASURES TO FIGHT COVID19: Is it enough?," New Age Youth desk, 2020. . 